\title{
Mating position in Peloridiidae (Hemiptera: Coleorrhyncha)
}

\section{Поза спаривания у Peloridiidae (Hemiptera: Coleorrhyncha)}

\author{
Dmitry E. Shcherbakov \\ A.E. Щербаков
}

Borissiak Paleontological Institute, Russian Academy of Sciences, Profsoyuznaya St. 123, Moscow 117647, Russia. E-mail: dshh@narod.ru. Палеонтологический институт им. А.А. Борисяка РАН, ул. Профсоюзная 123, Москва 117647, Россия.

KEY WORDS: relict, Chile, Tasmania, moss bugs, Auchenorrhyncha, Homoptera, Heteroptera, phylogeny, genitalia, copulation.

КЛЮЧЕВЫЕ СЛОВА: реликт, Чили, Тасмания, пелоридииды, цикадовые, равнокрылые, клопы, филогения, гениталии, копуляция.

ABSTRACT. The mating position is described and illustrated for the first time in Peloridiidae. Peloridium hammoniorum Breddin, 1897 from Chile and Hemiodoecus leai China, 1924 from Tasmania mate in the side-by-side (V-shaped) position, where the tips of male and female abdomens are actually in a female-above position (the female's posterior held between the male's genitalia below and his tegmina above). Such mating position, common in Psyllomorpha, Auchenorrhyncha and Heteroptera, is likely primitive for Hemiptera.

РЕЗЮМЕ. Впервые описано и изображено спаривание у Peloridiidae. Peloridium hammoniorum Breddin, 1897 из Чили и Hemiodoecus leai China, 1924 с Тасмании спариваются в боковой (V-образной) позиции, при этом вершина брюшка самца находится под брюшком самки (её задняя часть зажата между его гениталиями снизу и надкрыльями сверху). Подобная поза спаривания, обычная у Psyllomorpha, Auchenorrhyncha и Heteroptera, вероятно, примитивна для Hemiptera.

The modern family Peloridiidae includes 33 species from South America, Australia, New Zealand and New Caledonia [Burckhardt, 2009; Shcherbakov, 2014]. This phylogenetically highly isolated relict group represents the last remnant of the hemipteran suborder Coleorrhyncha that originated in the Late Permian and was diverse and widespread in the Mesozoic. Coleorrhyncha are often considered the sister group to Heteroptera, but the fossil record shows these groups as independent offshoots from primitive Cicadomorpha [Popov, Shcherbakov, 1991, 1996; Shcherbakov, Popov, 2002]. A recent phylogenomic analysis supports Peloridiidae as the sister group to Auchenorrhyncha [Johnson et al., 2018].

Peloridiids live on mosses and hepatics, and many aspects of their life history are still insufficiently known. For example, mating was observed in Hackeriella veit- chi (Hacker, 1932) [Helmsing, China, 1937] and Hemiodoecus leai China, 1924 [Wakelin, Lariviere, 2014], but not described. In some Peloridiidae, males were often seen riding on the backs of their conspecifics of both sexes, adults and last instar nymphs, probably before mating [R. Rakitov, pers. comm. 2013; Hartung, 2018]. However, no information was published on the mating position of Peloridiidae. Based on the cup-like pygophore and symmetrical parameres, Sweet [2006] predicted that in the Peloridiidae the male takes a position under the female much as in psocids.

During our field trips to Chile and Tasmania, we collected several species of Peloridiidae and kept them alive in captivity. Mating was observed in Peloridium hammoniorum Breddin, 1897 from Chiloé Island and Hemiodoecus leai from Lake St Clair (only once for each species). In both species, the pairs assumed a side-by-side (or V-shaped) position (terminology after Huber et al. [2007]; Figs 1-3). The male was to the left of the female in P. hammoniorum, and to the right, in $H$. leai, but the symmetric male genitalia of peloridiids suggest that the choice of the side is probably random. The male clasped the female's posterior part between his abdomen and his tegmina, folded in repose, the latter covering the female's tegmina and extending to or beyond her body midline, one of his hind legs on her back, and his abdomen under hers, so that the pair's genitalia were coupled in the female-above position. Peloridiids are normally flightless and lack hind wings (except for the rare macropterous form of P. hammoniorum), and are not sexually dimorphic in tegmen size. In subbrachypterous $P$. hammoniorum having relatively large and flat tegmina, the angle between male and female was nearly $90^{\circ}$ and the male's hind leg reached only to the precostal area of the female's tegmen, whereas in $H$. leai having smaller convex tegmina, the angle was about $60^{\circ}$ and the male's leg reached to the female's scutellum. Copulation was

How to cite this article: Shcherbakov D.E. 2021. Mating position in Peloridiidae (Hemiptera: Coleorrhyncha) // Russian Entomol. J. Vol.30. No.1. P.1-3. doi: 10.15298/rusentj.30.1.01 


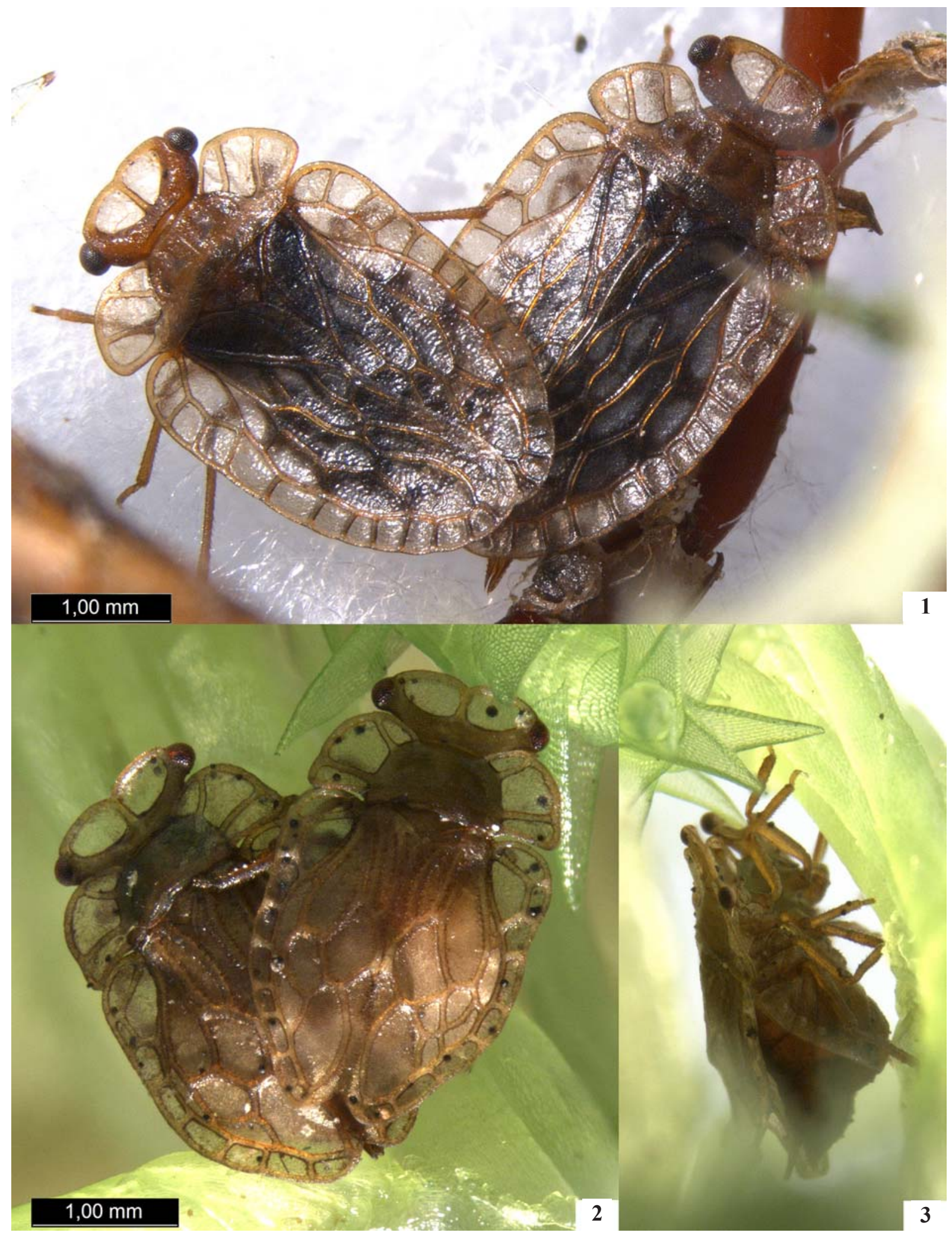

Figs 1-3. Mating Peloridiidae: 1 - Peloridium hammoniorum Breddin, 1897, dorsal view, male on the left; 2-3 - Hemiodoecus leai China, 1924: 2 - dorsal view, male on the right (note female right tegmen visible through male tegmina); black dots are ascomycete pycnidia [Helmsing, China, 1937: 487]; 3 - right lateral view, male in front.

Рис. 1-3. Спаривание у Peloridiidae: 1 - Peloridium hammoniorum Breddin, 1897, вид сверху, самец слева; 2-3 - Hemiodoecus leai China, 1924: 2 - вид сверху, самец справа (через его надкрылья просвечивает правое надкрылье самки); чёрные точки пикнидии аскомицетов [Helmsing, China, 1937: 487]; 3 - вид справа, самец спереди. 
prolonged, and no change of mating position was recorded during some 30 (P. hammoniorum) or 20 ( $H$. leai) minutes of observation. The beginning and the end of copulation were not observed.

The mating position described for these two genera belonging to the two of three geographically vicarious clades of Peloridiidae [Popov, Shcherbakov, 1996] is probably characteristic of the whole family. This sideby-side position with the tips of abdomens in a femaleabove position is common in Psylloidea, Aleyrodoidea, Cicadomorpha, many Fulgoroidea, and some Heteroptera, e.g. Leptopodomorpha [Weber, 1930; Kullenberg, 1947; Cobben, 1957; Huber et al., 2007 and references therein; Wang et al., 2009; Li et al., 2013], therefore it may be primitive for the whole Hemiptera. This position is derivable from a symmetric femaleabove position considered plesiomorphic for Pterygota [Alexander, 1964; McAlpine, 1981; Huber, 2010].

Acknowledgements. I am deeply grateful to Mario Elgueta (National Museum of Natural History, Santiago), the staff of the National Forest Corporation of Chile, Catherine Byrne and Simon Grove (both Tasmanian Museum and Art Gallery, Hobart) for facilitating our field work in protected areas of Chile and Tasmania. I heartily thank Roman Rakitov, Kirill Eskov (both Paleontological Institute, Moscow) and Elena Rodionova (Institute for Information Transmission Problems, Moscow) for their help in collecting peloridiids, and Alexander Emeljanov (Zoological Institute, St Petersburg) and Roman Rakitov for valuable comments. The field trips were supported by the Russian Foundation for Basic Research, project 13-04-01839.

\section{References}

Alexander R.D. 1964. The evolution of mating behavior in arthropods // R. entomol. Soc. London Symp. Vol.2. P.78-94.

Burckhardt D. 2009. Taxonomy and phylogeny of the Gondwanan moss bugs or Peloridiidae (Hemiptera, Coleorrhyncha) // Dtsch. entomol. Z. Vol.56. P.173-235.

Cobben R.H. 1957. Beitrag zur Kenntnis der Uferwanzen (Hem. Het. Fam. Saldidae) // Ent. Ber. Bd.17. S.245-257.

Hartung V. 2018. Systematics of Peloridiidae (Insecta: Hemiptera: Coleorrhyncha) - an integrative approach. PhD thesis. Berlin: Humboldt-Universität. 347 p.
Helmsing I.W., China W.E. 1937. On the biology and ecology of Hemiodoecus veitchi Hacker (Hemiptera, Peloridiidae) // Ann. Mag. nat. Hist. Ser.10. Vol.19. No.113. P.473-489.

Huber B.A. 2010. Mating positions and the evolution of asymmetric insect genitalia // Genetica. Vol.138. P.19-25.

Huber B.A., Sinclair B.J., Schmitt M. 2007. The evolution of asymmetric genitalia in spiders and insects // Biol. Rev. Vol.82. P.647-698.

Johnson K.P., Dietrich Ch.H., Friedrich F., Beutel R.G., Wipfler B., Peters R.S., Allen J.M., Petersen M., Donath A., Walden K.K.O., Kozlov A.M., Podsiadlowski L., Mayer Ch., Meusemann K., Vasilikopoulos A., Waterhouse R.M., Cameron S.L., Weirauch Ch., Swanson D.R., Percy D.M., Hardy N.B., Terry I., Liu S., Zhou X., Misof B., Robertson H.M., Yoshizawa K. 2018. Phylogenomics and the evolution of hemipteroid insects // PNAS. Vol.115. P.12775-12780. doi: 10.1073/pnas.1815820115.

Kullenberg B. 1947. Über Morphologie und Funktion des Kopulationsapparates der Capsiden und Nabiden // Zool. Bidr. Uppsala. Vol.24. S.217-418.

Li S., Shih C., Wang C., Pang H., Ren D. 2013. Forever love: the hitherto earliest record of copulating insects from the Middle Jurassic of China // PLOS One. Vol.8. e78188.

McAlpine J.F. 1981. Morphology and terminology - adults // J.F McAlpine, B.V. Peterson, G.E. Shewell, H.J. Teskey, J.R. Vockeroth, D.M. Wood (eds.). Manual of Nearctic Diptera. Vol.1. Agriculture Canada Monograph. Vol.27. P.9-63.

Popov Yu.A., Shcherbakov D.E. 1991. Mesozoic Peloridioidea and their ancestors (Insecta: Hemiptera, Coleorrhyncha) // Geol. Palaeontol. Vol.25. P.215-235.

Popov Yu.A., Shcherbakov D.E. 1996. Origin and evolution of the Coleorrhyncha as shown by the fossil record // C.W. Schaefer (ed.). Studies on Hemipteran Phylogeny. Lanham (Maryland): Entomological Society of America. P.9-30.

Shcherbakov D.E. 2014. A new species of Peloridium (Hemiptera: Coleorrhyncha, Peloridiidae) from Chile // Far East. Entomol. No.286. P.1-11.

Shcherbakov D.E., Popov Yu.A. 2002. Order Hemiptera Linné, 1758. The bugs, cicadas, plantlice, scale insects, etc. // A.P. Rasnitsyn, D.L.J. Quicke (eds.). History of Insects. Dordrecht: Kluwer. P.143-157.

Sweet M.H. 2006. Justification for the Aradimorpha as an infraorder of the suborder Heteroptera (Hemiptera, Prosorrhyncha) with special reference to the pregenital abdominal structure // Denisia. Vol.19. P.225-248.

Wakelin M.D., Lariviere M.-C. 2014. First New Zealand record of the Australian species Hemiodoecus leai China, 1924 (Hemiptera: Peloridiidae); a hitchhiker on moss // Zootaxa. Vol.3884. P.95-100.

Wang R.R., Liang A.P., Webb M.D. 2009. A new tropiduchid planthopper genus and species from China with descriptions of in copula genitalic structures (Hemiptera: Fulgoromorpha) // Syst. Entomol. Vol.34. P.434-442.

Weber H. 1930. Die Biologie der Hemipteren. Berlin: Springer. vii+543 S. 